\title{
ANALISIS SEMIOTIKA PEIRCE DALAM PENGGUNAAN ISTILAH EMPAT PILAR BERBANGSA DAN BERNEGARA MPR RI
}

\author{
Hastangka, Armaidy Armawi, dan Kaelan \\ Fakultas Filsafat Universitas Gadjah Mada \\ email: hastangka@gmail.com
}

\begin{abstract}
Abstrak
Penggunaan istilah "Empat Pilar Berbangsa dan Bernegara" sebagai program sosialisasi MPR RI telah menimbulkan perdebatan. Istilah yang digunakan sejak tahun 2009 ini memberi dampak pada aspek linguistik di antaranya aspek sosiolinguistik, semantik, pragmatik, dan semiotika bahasa. Penelitian ini bertujuan mendeskripsikan persoalan semiotik penggunaan istilah Empat Pilar Berbangsa dan Bernegara oleh MPR RI, yakni Pancasila, UUD 1945, NKRI, dan Bhinneka Tunggal Ika. Data yang digunakan dalam penelitian ini berupa frasa Empat Pilar Berbangsa dan Bernegara. Pengumpulan data dilakukan menggunakan inventarisasi data, kategorisasi data, dan klarifikasi data. Data dianalisis dengan teknik analisis semiotika. Hasil penelitian sebagai berikut. Pertama, istilah "Empat Pilar Berbangsa dan Bernegara" merupakan proposisi unik dan tidak lazim dalam konteks sosiolinguistik masyarakat Indonesia. Kedua, istilah Empat Pilar Berbangsa dan Bernegara yang mengkategorikan Pancasila, UUD 1945, NKRI, dan Bhinneka Tunggal Ika merupakan bentuk kesalahan semantik dan pragmatik. Ketiga, secara aturan penulisan simbol dan tanda, istilah tersebut bertentangan dengan hakikat kedudukan dan fungsi dari Pancasila, UUD 1945, NKRI, dan Bhinneka Tunggal Ika karena dijadikan sebagai satu varian yang sama, yaitu pilar. Keempat, penggunaan istilah Empat Pilar Berbangsa dan Bernegara telah mengacaukan sistem tanda dan simbol, terutama pada makna semiotis Pancasila, UUD 1945, NKRI, dan Bhinneka Tunggal Ika.
\end{abstract}

Kata Kunci: bahasa, empat pilar, semiotik, simbol

\section{PEIRCE'S SEMIOTIC ANALYSIS OF THE USE OF THE TERM "FOUR NATION AND STATE PILLARS"BY MPR RI}

\begin{abstract}
The use of the term "Four Nation and State Pillars" as a socialization program of MPR (People's Consultative Assembly) RI (Republic of Indonesia) results in debates. The term, which has been used since 2009, gives a significant impact on linguistic aspects, especially in sociolinguistic, semantic, pragmatic, and semiotic aspects. This study aims to describe and analyze semiotic problems in the use of the term "Four Nation and State Pillars"by MPR RI, namely Pancasila, the 1945 Constitution, the Unitary State of the Republic of Indonesia, and Unity in Diversity. The research data were from the phrase "Four Nation and State Pillars". They were collected using the data inventory, data categorization, and data clarification. They were analyzed using the semiotic analysis technique. The findings are as follows. First, the term "Four
\end{abstract}


Nation and State Pillars" is a unique and unusual proposition in the sociolinguistic context of Indonesian society. Second, the term, which categorizes Pancasila, the 1945 Constitution, the Unitary State of the Republic of Indonesia, and Unity in Diversity, becomes a semantic and pragmatic mistake. Third, based on symbol and sign writing rules, the term contradicts the position and functionof Pancasila, the 1945 Constitution, the Unitary State of the Republic of Indonesia, and Unity in Diversity, because they are classified into the same variants, namely pillars. Fourth, the use of the term "Four Nation and State Pillars" has disrupted the system of signs and symbols, especially the semiotic meanings of Pancasila, the 1945 Constitution, the Unitary State of the Republic of Indonesia, and Unity in Diversity.

Keywords: language, four pillars, semiotics, symbol

\section{PENDAHULUAN}

Bahasa merupakan hal yang esensial dalam fenomena sosial. Melalui bahasa, orang dapat berbagi pengalaman. Setiap orang menggunakan bahasa untuk mendeskripsikan masa lalu, situasi sekarang, atau masa depan. Bahasa bertujuan untuk mengekspresikan keinginan, harapan, emosi, perintah, pernyataan atas fakta. Oleh karena itu, fungsi dasar bahasa ialah alat komunikasi (Prasad, 2002:1; Keraf, 1984:17). Tanpa bahasa, manusia menjadi tidak bermakna. Black mengistilahkan dalam tulisannya pada The Journal of Philosophy menyebut "Men without language would be subhuman animals" (Black, 1962:506).

Keraf menjelaskan bahasa sebagai alat komunikasi yang memiliki dua bagian besar yaitu bentuk (arus ujaran) dan makna (isi). Bentuk bahasa terdiri atas bagian bahasa yang dapat diserap panca indera baik dengan mendengar atau dengan membaca. Sedangkan, makna adalah isi yang terkandung di dalam bentuk-bentuk bahasa, yang dapat menimbulkan reaksi tertentu. Reaksi-reaksi tersebut dapat timbul karena mendengar kata tertentu, mendengar atau membaca rangkaian kata-kata yang membentuk frasa, klausa, kalimat, atau sesudah membaca atau mendengar sebuah wacana (makna wacana). Semua bidang makna tersebut yang dipelajari dalam cabang ilmu bahasa disebut semantik (Keraf, 1984:16-17).

Ada dua faktor pendukung bahasa yaitu: lambang/tanda (suatu yang lazim dipergunakan dalam masyarakat yang artinya ditaati secara spontan), dan bunyi bahasa (fonem). Kedua faktor itu saling mempengaruhi satu sama lain dalam pembentukan dan penyusunan bahasa (Mustansyir, 1988:20).

Menurut Wittgenstein, kata memiliki makna tindak karena berasal dari tindakan atau objek yang ditunjuk tetapi berasal dari konteks sejarah wacana atau permainan bahasa yang digunakan. Makna kata memiliki aturan yang secara masuk akal dibentuk di dalam konteks institusional dimana bahasa tersebut digunakan (Mauws dan Phillips, 1995:323).

Istilah Empat Pilar Berbangsa dan Bernegara yang digunakan oleh Majelis Permusyawaratan Rakyat Republik Indonesia (MPR RI) sejak akhir tahun 2009 lalu telah menimbulkan perdebat- 
an dan persoalan terkait istilah bahasa, filsafat, dan linguistik. Empat Pilar yang terdiri atas Pancasila, UndangUndang Dasar Republik Indonesia tahun 1945, Negara Kesatuan Republik Indonesia (NKRI), dan Bhinneka Tunggal Ika, yang digunakan sebagai program sosialisasi, mendapatkan kritikan dari masyarakat dan akademisi. Istilah Empat Pilar Berbangsa dan Bernegara ini mulai diperkenalkan oleh Taufiq Kiemas, Ketua MPR RI periode 2009-2014, sebagai program unggulan MPR RI paska reformasi. Pada awalnya, tepatnya sebelum paska reformasi, MPR RI merupakan lembaga negara yang memiliki kedudukan yang penting dalam sistem dan struktur tata negara di Indonesia sebagai lembaga tertinggi negara. Namun, kedudukan tersebut dihapuskan melalui amandemen UUD 1945 yang telah mereduksi peran MPR RI sebagai lembaga tertinggi negara yang kemudian menjadi lembaga tinggi negara.

Kedudukan MPR RI sebagai lembaga tinggi negara dinilai memiliki peran yang kurang signifikan dalam kehidupan ketatanegaraan di Indonesia. Oleh karena itu, MPR RI memiliki program baru yang disebut Sosialisasi Empat Pilar Berbangsa dan Bernegara. Sejak adanya program ini, istilah Empat Pilar mulai diperkenalkan kepada masyarakat melalui berbagai bentuk dan program seperti seminar Empat Pilar, Sosialisasi Empat Pilar, Talkshow Empat Pilar, Diskusi Empat Pilar, Lomba Cerdas Cermat Empat Pilar, Pelatihan Empat Pilar, dan penulisan buku Empat Pilar. Istilah dan penggunaan bahasa Empat Pilar Berbangsa dan Bernegara telah memasukkan Pancasila, UUD 1945, NKRI, dan Bhin- neka Tunggal Ika sebagai kategori yang sama yaitu pilar. Hal ini membawa persoalan pemaknaan terhadap Pancasila sebagai dasar negara berubah menjadi pilar, UUD 1945 sebagai norma dasar berubah menjadi pilar, NKRI sebagai bentuk negara berubah menjadi pilar, dan Bhinneka Tunggal Ika sebagai semboyan negara berubah dimaknai menjadi pilar.

Persoalan lain yang muncul dari aspek bahasa ialah struktur dan logika bahasa yang digunakan oleh MPR RI yang dinilai menyimpang dan tidak lazim. Bahasa merupakan sistem tanda dan alat komunikasi untuk menyampaikan pesan kepada orang lain. Bahasa bekerja dalam kerangka untuk mengkomunikasikan informasi, perasaan, ide, dan sistem-sistem yang telah mapan dipelajari orang. Seperti adanya tata bahasa untuk penulisan dan percakapan dan tata bahasa untuk bermacam-macam teks juga untuk media yang berbedabeda (Budi, 2000:13). Apabila bahasa yang digunakan sebagai alat menyampaikan pesan tersebut memiliki makna yang ambigu, makna bahasa yang ditangkap akan cenderung berbeda.

Secara sosiolinguistik, pemahaman masyarakat tentang bahasa dan istilah menunjukkan bahwa Pancasila dikenal dan dipahami sebagai dasar negara, UUD 1945 sebagai konstitusi atau norma dasar negara Indonesia, NKRI sebagai bentuk negara, dan Bhinneka Tunggal Ika sebagai semboyan negara.

Polemik penggunaan istilah Empat Pilar Berbangsa dan Bernegara yang digunakan oleh MPR RI telah memunculkan persoalan yang fundamental dalam kajian bahasa dan linguistik, terutama semiotika. Menurut peneliti, studi ini menarik untuk diteliti dikarenakan 
fenomena penggunaan istilah Empat Pilar Berbangsa dan Bernegara tersebut tidak hanya sekedar sebagai fenomena tata bahasa, tetapi juga menimbulkan persoalan sosiolingustik dan politik linguistik. Pada aspek yang mendasar istilah Empat Pilar Berbangsa dan Bernegara akan dianalisis menggunakan kerangka semiotika Charles Sanders Peirce.

Semiotika adalah studi tentang tanda dan segala yang berhubungan dengannya: cara berfungsinya, hubungannya dengan tanda-tanda lain dengan pengirim dan penerimanya. Secara umum analisis semiotika dapat dibedakan menjadi tiga yaitu; 1). semiotik sintaksis ialah studi tanda yang berpusat pada hubungan dengan tanda lain, cara kerja atau fungsi tanda; 2). Semiotik semantik, ialah memfokuskan pada hubungan tanda-tanda dengan acuannya dan interpretasi yang dihasilkan; dan 3). Semiotik pragmatik, ialah memfokuskan pada hubungan antara tanda dengan pengirim dan penerimanya (Zoest, 1992: 5-6).

Eco menjelaskan bahwa terdapat tiga batas penelitian semiotika yaitu batas politik, batas alam dan batas epistemologis. Batas politik diistilahkan lain oleh Eco supaya tidak menimbulkan konotasi yang menyesatkan menjadi ranah budaya, ranah alam, dan ranah epistemologis (Eco, 1992:29).

Tujuan dari penelitian ini adalah untuk mengungkap ambiguitas istilah Empat Pilar Berbangsa dan Bernegara dari aspek semiotika. Selain itu juga untuk mendeskripsikan serta menganalisis makna simbolik dibalik istilah Empat Pilar Berbangsa dan Bernegara serta dampaknya terhadap pemaham- an masyarakat tentang representasi simbolik dari Pancasila, UUD 1945, NKRI, dan Bhinneka Tunggal Ika.

\section{METODE}

Penelitian ini merupakan penelitian kualitatif dengan pendekatan analisis semiotika bahasa dari perspektif teori semiotika Charles Sanders Peirce. Objek penelitian ini ialah istilah "Empat Pilar Berbangsa dan Bernegara" yang digunakan oleh MPR RI yang terdiri atas Pancasila, UUD 1945, NKRI, dan Bhinneka Tunggal Ika. Data penelitian ini diambil dari data pustaka yaitu buku, peraturan perundang-undangan, artikel berita baik cetak maupun elektronik, majalah Majelis yang diterbitkan oleh MPR RI, dan jurnal ilmiah. Teknik pengumpulan data dilakukan melalui inventarisasi data, riset kepustakaan, dan kategorisasi data. Teknik analisis data dalam penelitian ini menggunakan interpretasi berdasarkan kerangka Semiotika Peirce trikotomi (segitiga makna) yaitu: sign (tanda), object (objek), dan interpretant (interpretan). Menurut Peirce, ada tiga faktor yang menentukan adanya sebuah tanda, yaitu tanda itu sendiri, hal yang ditandai, dan sebuah tanda baru yang terjadi dalam batin penerima (Suantoko, 2017:43). Dalam teori segitiga makna Peirce, salah satu bentuk tanda adalah kata; objek adalah suatu yang dirujuk tanda; sedangkan interpretan adalah tanda yang ada dibenak seseorang tentang objek yang dirujuk oleh tanda. Apabila ketiga elemen makna itu berinteraksi dalam pikiran seseorang, maka muncul makna tentang sesuatu yang diwakili oleh tanda tersebut (Sobur, 2009:12). 


\section{HASIL DAN PEMBAHASAN Wacana Empat Pilar Berbangsa dan Bernegara}

MPR RI memproduksi istilah Empat Pilar Berbangsa dan Bernegara dalam wacana di media terutama majalah Majelis yang diterbitkan secara berkala setiap bulan sebagai "rumah kebangsaan pengawal Ideologi Pancasila dan kedaulatan rakyat (Majalah Majelis, edisi No.01/TH.XI/Januari 2017, hal 2). Istilah "Sosialisasi Empat Pilar Kehidupan Berbangsa dan Bernegara" yang terdiri atas Pancasila, UUD 1945, NKRI, dan Bhinneka Tunggal Ika mulai dikenal sejak MPR RI dipimpin oleh Taufiq Kiemas, Ketua MPR RI periode 2009-2014. Pada masa kepemimpinan Hidayat Nur Wahid (2004-2009), MPR RI hanya menggunakan istilah "Sosialisasi putusan MPR". Sejak Taufiq Kiemas terpilih secara aklamasi, istilah Empat Pilar menjadi wacana publik. Gagasan Empat Pilar bertujuan menjelaskan kepada masyarakat pentingnya menjaga NKRI dengan mengamalkan Pancasila, menjalankan konstitusi, dan menghargai kebhinnekaan (Majalah Majelis, edisi No.12/TH.X/Desember 2016, hal.6).

Pada tahun 2011, istilah Empat Pilar Berbangsa dan Bernegara mendapatkan legitimasi secara yuridis melalui terbitnya Undang-Undang No. 2 tahun 2011 tentang Perubahan atas UndangUndang Nomor 2 tahun 2008 tentang partai politik pasal 34 ayat (3b) poin a yang menyebutkan bahwa:

"Pendidikan politik sebagaimana dimaksud pada ayat ( $3 a$ ) berkaitan dengan kegiatan: a. pendalaman mengenai empat pilar berbangsa dan bernegara yaitu Pancasila, UUD 1945, Bhinneka Tunggal Ika dan Negara Kesatuan Republik Indonesia".

Istilah Empat Pilar Berbangsa dan Bernegara menjadi populer dalam kehidupan masyarakat. Setelah menjadi UU istilah empat pilar kehidupan berbangsa dan bernegara digunakan oleh MPR RI untuk memasyaratkan pendidikan politik. Tim kerja sosialisasi empat pilar kehidupan berbangsa dan bernegara dari MPR RI menyatakan bahwa:

"Penyebutan Empat Pilar kehidupan berbangsa dan bernegara tidaklah dimaksudkan bahwa keempat pilar tersebut memiliki kedudukan yang sederajat.Setiap pilar memiliki tingkat, fungsi, dan konteks yang berbeda. Dalam hal ini posisi Pancasila tetap ditempatkan sebagai nilai fundamental berbangsa dan bernegara. Empat pilar dari konsepsi kenegaraan Indonesia tersebut merupakan prasyarat minimal bagi bangsa ini untuk bisa berdiri kukuh dan meraih kemajuan berlandaskan karakter kepribadian bangsa Indonesia sendiri. Setiap warga Negara Indonesia harus memiliki keyakinan, bahwa itulah prinsip-prinsip moral keindonesian yang memandu tercapainya perikehidupan bangsa yang merdeka, bersatu, berdaulat, adil, dan makmur" (Pimpinan MPR RI dan Tim kerja Sosialisasi MPR RI periode 2009-2014, 2012:xii).

MPR RI memberikan pengertian tentang empat pilar kehidupan berbangsa dan bernegara merupakan kumpulan nilai-nilai luhur yang harus dipahami oleh seluruh masyarakat dan menjadi panduan dalam kehidupan 
ketatanegaraan untuk mewujudkan bangsa dan negara yang adil, makmur, sejahtera, dan bermartabat (Pimpinan MPR RI dan Tim kerja Sosialisasi MPR RI periode 2009-2014, 2012:xx). Istilah "pilar" yang digunakan oleh MPR RI untuk menyebut empat pilar merujuk pada Kamus Besar Bahasa Indonesia (edisi III tahun 2008) yang menyatakan bahwa pilar mengandung pengertian sebagai tiang penguat, dasar, yang pokok, atau induk (Pimpinan MPR RI dan Tim kerja Sosialisasi MPR RI periode 2009-2014, 2012:6). MPR RI dalam keterangan pada sidang uji materiil UU Nomor 2 Tahun 2011 pada tanggal 17 Februari 2014 di Mahkamah Konstitusi juga menjelaskan bahwa istilah "pilar" dalam empat pilar kehidupan berbangsa dan bernegara dimaknai sebagai hal yang pokok, mendasar dan esensial dalam kehidupan bangsa Indonesia yang memiliki sifat dinamis (salinan Putusan Mahkamah Konstitusi RI Nomor 100/PUUXI/2013, 2014:72).

Istilah Empat Pilar Berbangsa dan Bernegara dalam perkembangannya mendapatkan berbagai kritik secara kebahasaan dan pemaknaan. Hadiatie berpendapat bahwa penggunaan istilah Empat Pilar secara makna bahasa dapat dianalogikan sebagai suatu bangunan. Perumpamaan ini menunjukkan bahwa kata "pilar" berarti bagian bangunan atap rumah yang menghubungkan atap dengan pondasi yang membuat bangunan bisa berdiri tegak. Posisi Pancasila yang diletakkan sebagai pilar menjadi ambigu. Hal ini dikarenakan bahwa Pancasila merupakan dasar, ibarat rumah yang berfungsi sebagai fondasi, bukan sebagai pilar. Begitu juga istilah UUD 1945, NKRI, dan Bhinneka
Tunggal Ika tidak dapat disejajarkan sebagai pilar karena akan mengubah makna (kompasiana.com, 7 Januari 2014).

Menurut Wildan, rumusan Empat Pilar yang terdiri atas Pancasila, UUD 1945, NKRI, dan Bhinneka Tunggal Ika tidak pernah dijelaskan oleh MPR RI dari mana asal mulanya. Seolaholah doktrin Empat Pilar Berbangsa dan Bernegara tersebut diterima begitu saja tanpa meninjau asal usul data sejarah dan asal mula terbentuknya sejarah bangsa Indonesia. Hasil kajian Wildan dari aspek sejarah terbentuknya kata Empat Pilar Berbangsa dan Bernegara tersebut dinilai tidak bersumber dari preambule UUD 1945 (kompasiana.com, 20 Juli 2013).

Supardiyono juga berpendapat melalui analisis struktur frasa Empat Pilar. Menurutnya, dari aspek terbentuknya dan asal mulanya, Pancasila merupakan dasar negara, bukan pilar. Begitu pula dengan UUD 1945 yang dilihat aspek terbentuknya dalam ilmu tata negara merupakan hukum dasar, sehingga kurang tepat apabila disebut sebagai pilar. NKRI dalam UUD 1945 pasal 1 ayat (1) berbunyi: "Negara Indonesia ialah Negara Kesatuan, yang berbentuk Republik". Bunyi pasal tersebut secara bahasa yuridis formal merupakan artikulasi tentang bentuk negara. Negara Kesatuan Republik Indonesia (NKRI) merupakan bentuk negara. Bhinneka Tunggal Ika merupakan semboyan negara sebagaimana tertulis dalam bahasa formal yuridis pada UUD 1945 amandeman kedua pasal 36A yang berbunyi "Lambang Negara ialah Garuda Pancasila dengan semboyan Bhinneka Tunggal Ika" (kompasiana. 
com, 26 Agustus 2013; Pasal 36A UUD 1945 Amandemen Kedua).

\section{Asal Muasal Istilah Empat Pilar Ber- bangsa dan Bernegara}

Taufiq Kiemas menggagas istilah Empat Pilar Berbangsa dan Bernegara saat beliau terpilih secara aklamasi sebagai ketua MPR RI periode 20092014. Pada saat itu, beliau mengadakan rapat dengan para ketua fraksi MPR untuk menyusun program sosialisasi UUD 1945 termasuk Pancasila. Rapat tersebut menghasilkan gagasan Empat Pilar Berbangsa dan Bernegara dari ketua MPR RI dan menguraikan pentingnya menjaga NKRI dan mengamalkan Pancasila (detiknews, 10 Juni 2013).

Selain banyaknya kritik akan istilah Empat Pilar Berbangsa dan Bernegara, ada pula pernyataan yang berbeda dari MPR RI yang disampaikan oleh Wakil Ketua MPR RI, Hajriyanto Y Thohari. Beliau mengatakan penggunaan istilah 4 Pilar hanya sebatas untuk menarik (eye catching) dalam bahasa komunikasi. Menurutnya, di dalam sosialisasi akan lebih menekankan pada substansi dan menyebut juga Pancasila sebagai dasar negara (news.okezone.com, 30 September 2013). Kalangan akademisi menyampaikan perbedaan pendapat dengan MPR RI terkait penggunaan istilah Empat Pilar tersebut sebagaimana yang diungkap oleh Sudjito bahwa:

"memasukannya Pancasila sebagai salah satu pilar kebangsaan selain UUD 1945, Bhinneka Tunggal Ika dan NKRI dianggap menyesatkan pemahaman masyarakat terhadap keberadan Pancasila sebagai ideologi bangsa. Yang muncul dari masyarakat bisa menganggap Pancasila itu dasar negara atau pilar ke- bangsaan" (ugm.ac.id, 11 September 2013).

Penggunaan istilah Empat Pilar yang mengkategorikan Pancasila sebagai salah satu pilar telah membawa persoalan terhadap aspek semantik yaitu ketidakpastian pemaknaan atas Pancasila sebagai pilar atau dasar negara. Selain itu, asal muasal istilah Empat Pilar Berbangsa dan Bernegara tidak memiliki dasar sosiolinguistik yang memadai. Bahasa memiliki peran dan fungsi untuk mentransformasikan nilai, pesan, dan makna tertentu kepada masyarakat. Masyarakat dan budaya membentuk bahasa dan begitu juga sebaliknya, bahasa membentuk masyarakat dan budaya. Pada aspek pragmatik, istilah Empat Pilar dimaknai secara berbeda. Maksud dari pembicara yang direpresentasikan oleh lembaga negara yaitu MPR RI hendak menyampaikan pesan dan gagasan tentang pentingnya nilai-nilai kebangsaan. Namun istilah Empat Pilar diterima oleh masyarakat dalam konteks yang berbeda yaitu menyimpang dari makna yang sebenarnya. Pancasila dikatakan sebagai pilar, UUD 1945 disebut sebagai pilar, NKRI disebut sebagai pilar, dan Bhinneka Tunggal Ika sebagai pilar.

\section{Bentuk Lingual Istilah Empat Pilar Berbangsa dan Bernegara}

Secara morfologis, istilah Empat Pilar Berbangsa dan Bernegara memiliki bentuk lingual yang tersusun atas beberapa elemen yaitu: 1). unsur numerlia yaitu "Empat, (4)" sebagai bilangan angka; 2). Pilar merupakan unsur nomina; 3). Berbangsa dan Bernegara merupakan unsur verba (kata kerja). Se- 
dangkan Pancasila, UUD 1945, NKRI, dan Bhinneka Tunggal Ika merupakan istilah khusus dan baku kenegaraan atau istilah nasional yang digunakan untuk mendefinisikan dan mengartikan makna istilah tersebut sesuai dengan unsur fisisnya (kondisi keadaan alamiah bahasa tersebut).

Pada tahun 2014, bentuk lingual istilah Empat Pilar Berbangsa dan Bernegara berubah menjadi Empat Pilar MPR RI. Istilah ini mengalami proses perubahan morfologis yang unsurnya sama dan terdiri dari berbagai elemen pembentukan kata. Dalam hal ini, istilah Empat Pilar Berbangsa dan Bernegara memiliki struktur bentuk lingual yang kompleks dan tidak teratur.

Hasil kajian ini menunjukkan bentuk lingual yang digunakan oleh MPR RI dalam memahami dan merumuskan istilah Empat Pilar Berbangsa dan Bernegara. Istilah tersebut dibentuk dari tiga konsepsi sejarah bahasa politik yang berkembang terkait dengan pendidikan politik dalam sejarah Indonesia. Asumsi umum menyebutkan bahwa, pada masa orde baru pernah dikenal istilah P4 (Pedoman, Penghayatan, Pengamalan, dan Pancasila) yang memiliki tujuan untuk memberikan pesan kepada masyarakat akan pentingnya pembangunan karakter bangsa melalui $\mathrm{P} 4$.

Istilah 4 dalam Empat Pilar Berbangsa dan Bernegara ditemukan suatu keberlanjutan sejarah bahasa terkait pendidikan politik yang terinspirasi angka yang digunakan pada masa orde baru dalam konteks sosialisasi P4. Angka 4 ini kemudian digunakan untuk merumuskan program MPR RI yang disebut Sosialisasi Empat Pilar Berbangsa dan Bernegara atau Empat Pilar MPR
RI. Penelitian ini menunjukkan bahwa angka 4 tidak muncul begitu saja tanpa ada rangkaian dan latar belakang sejarah. Fakta yang mendekati sejarah dan asal muasal angka 4 dalam perumusan Empat Pilar Berbangsa dan Bernegara ialah konsepsi P4 yang apabila dibalik menjadi 4P (yang berarti 4 Pilar).

Ditinjau dari aspek semantik, yang dilihat dari isi materi, Empat Pilar Berbangsa dan Bernegara tidak memiliki hubungan secara langsung dalam peristiwa sejarah bangsa atau pembentukan istilah Empat Pilar itu sendiri. Penamaan Empat Pilar Berbangsa dan Bernegara telah menimbulkan persoalan kekacauan semantik (semantic confussion). Kekacauan semantik ini dapat diperlihatkan dari penggunaan istilah Empat Pilar Berbangsa dan Bernegara yang dimaknai sebagai Pancasila, UUD 1945, NKRI, dan Bhinneka Tunggal Ika. Semua itu memiliki makna yang berbeda dengan pilar. Kedudukan dan fungsi Pancasila, UUD 1945, NKRI, dan Bhinneka Tunggal Ika berbeda dengan maksud dan tujuan dari penggunaan istilah Empat Pilar Berbangsa dan Bernegara yang semuanya disebut sebagai pilar.

Dekonstruksi pemaknaan atas Pancasila, UUD 1945, NKRI, dan Bhinneka Tunggal Ika di dalam penggunaan istilah Empat Pilar Berbangsa dan Bernegara telah membawa persoalan penyimpangan makna atas istilah baku dan resmi kenegaraan. Secara sosiohistoris linguistik, dapat ditunjukkan bahwa istilah Empat Pilar Berbangsa dan Bernegara yang digunakan oleh MPR RI tidak memiliki dasar sosiologis dan historis dalam konteks sejarah sosial pembentukan bahasa. Sehingga istilah ini dinilai tidak lazim digunakan 
dan ambigu dengan menyebutkan Empat Pilar Berbangsa dan Bernegara terdiri atas Pancasila, UUD 1945, NKRI, dan Bhinneka Tunggal Ika. Dalam istilah Kamus Besar Bahasa Indonesia (KBBI) menunjukkan definisi secara harfiah "pilar" ialah tiang penyangga. Sehingga apabila diterapkan untuk keempat istilah yang dimasukkan maka Pancasila adalah tiang, UUD 1945 adalah tiang, NKRI adalah tiang, dan Bhinneka Tunggal Ika adalah tiang.

Secara sosiolinguistik, pembentukan istilah Empat Pilar Berbangsa dan Bernegara tidak dapat diterima oleh masyarakat, Dalam sejarah pembentukan Pancasila, UUD 1945, NKRI, dan Bhinneka Tunggal Ika juga tidak dikenal istilah pilar.Berdasarkan dari dokumen historis dan yuridis menunjukkan bahwa Pancasila tidak dapat dimaknai sepadan atau sejajar dengan UUD 1945, dan Bhinneka Tunggal Ika tidak dapat dimaknai sejajar dan sepadan dengan NKRI. Istilah Empat Pilar Kehidupan Berbangsa dan Bernegara baru dikenal sejak adanya gagasan sosialisasi oleh MPR RI melalui pasal 34 ayat (3b). Undang-Undang No. 2 tahun 2011 tentang perubahan atas UndangUndang Nomor 2 tahun 2008 tentang partai politik berdasarkan fakta historis, fakta sosiologis, dan kajian filosofis menyatakan bahwa Pancasila, UUD 1945, NKRI, dan Bhinneka Tunggal Ika bukanlah pilar. Pada konteks penafsiran historis, yaitu penafsiran tentang konstitusi yang didasarkan pada aspek sejarah hukum dan sejarah perumusan undang-undang (Lestaria,2014:29).

Berdasarkan penafsiran ini, istilah Empat Pilar yang digunakan oleh MPR RI terbukti tidak dapat dipertanggungjawabkan karena secara sejarah hukum ataupun sejarah perumusan undangundang di negara Indonesia tidak pernah dikenal sebelumnya.

Fakta historis menunjukkan bahwa Pancasila merupakan dasar negara sebagaimana tersirat dan tersurat pada sila-sila Pancasila dalam pembukaan UUD 1945. Dalam sejarah pemikiran perumusan Pancasila dan dokumen arsip resmi negara, Pancasila, UUD 1945, NKRI, dan Bhinneka Tunggal Ika tidak ditemukan sebagai bagian dari Empat Pilar Kehidupan Berbangsa dan Bernegara. Pasal 36A UUD 1945 menyatakan bahwa lambang negara ialah Garuda Pancasila dengan semboyan Bhinneka Tunggal Ika. Pasal tersebut secara jelas menegaskan bahwa Bhinneka Tunggal Ika sebagai semboyan negara bukan sebagai pilar atau bagian dari Empat Pilar Kehidupan Berbangsa dan Bernegara.

\section{Semiotik Peirce dalam Empat Pilar Berbangsa dan Bernegara}

Empat Pilar Kehidupan Berbangsa dan Bernegara yang telah dirumuskan oleh MPR RI menunjukkan suatu kelemahan atas istilah dan makna yang digunakan menimbulkan pemahaman yang ambigu. Empat Pilar Kehidupan Berbangsa dan Bernegara yang di dalamnya terdiri unsur Pancasila, UUD 1945, NKRI, dan Bhinneka Tunggal Ika tidak dapat diposisikan sebagai kategori yang sama atau kelompok kata yang memiliki makna yang sama sebagaimana yang dimaksud sebagai pilar kehidupan berbangsa dan bernegara.

Kerangka Peirce dalam teori trikotomi menjelaskan tentang kerangka semiotik atas bahasa yaitu: kaki pertama terdapat istilah representamen (suatu yang merepresentasikan), pada kaki 
kedua terdapat objek (sesuatu yang direpresentasikan/konsep), dan pada kaki ketiga, terdapat interpretant, yakni makna atau interpretasi tentang makna dalam benak seseorang (Saidi, 2018:7). Berdasarkan pada teori trikotomi Peirce tersebut, Empat Pilar Kehidupan Berbangsa dan Bernegara atau Empat Pilar MPR RI sebagai sebuah rumusan terletak pada posisi yang merepresentasikan (representamen) suatu objek. Objek ini diwakili oleh lembaga MPR RI karena yang memproduksi istilah dan program Empat Pilar adalah MPR RI sendiri. Istilah Empat Pilar Kehidupan Berbangsa dan Bernegara atau Empat Pilar MPR RI menjadi bermasalah ketika sampai pada kaki ketiga yakni proses pemaknaan yang dilakukan oleh interpretan. Maksud awal pesan, makna, dan tujuan yang hendak disampaikan oleh MPR RI ialah untuk memperkenalkan kembali "nilai-nilai kebangsaan" yang hilang sejak pasca reformasi. Namun, penggunaan istilah tersebut justru membuat persoalan.

Tanggapan interpretan dalam merespon istilah Empat Pilar Kehidupan Berbangsa dan Bernegara dapat dikategorikan menjadi tiga yaitu: rheme (interpretasi spontan), dicent (interpretasi yang telah spesifik), dan argument (interpretasi yang telah berdasar). Pada level rheme dan dicent, beberapa pihak telah mengungkapkan secara spontan, emosional, dan seruan/teriakan seperti demonstrasi yang dapat ditemukan dari beberapa pemberitaan di media. Semua demonstrasi itu mengacu kepada ketidaksetujuan dan sikap beberapa pihak atas penggunaan konsep Empat Pilar Kehidupan Berbangsa dan Bernegara. Dan lagi, hal ini berkaitan dengan permasalahan yang memasukkan Pan- casila, UUD 1945, NKRI, dan Bhinneka Tunggal Ika sebagai kategori pilar. Kemudian menjadi terlegitimasi dan argumentatif dengan tulisan yang ditulis oleh Kaelan yang berjudul "Problem Epistemologis Empat Pilar Berbangsa dan Bernegara" pada tahun 2012. Putusan Mahkamah Konstitusi Nomor 100/PUU-XI/2013 juga menyatakan bahwa Empat Pilar bertentangan dengan UUD 1945 dan tidak memiliki kekuatan hukum yang mengikat.

Posisi Empat Pilar Kehidupan Berbangsa dan Bernegara sebagai representamen dapat dilihat dari relasi segitiga tanda yang lain, yaitu: qualisign (sesuatu yang berpotensi menjadi tanda), sinsign (sesuatu yang telah dapat diduga sebagai tanda), dan legisign (sesuatu yang telah sahih sebagai tanda). Persoalan awal yang muncul bertitik tolak pada sinsign, bahwa Pancasila, UUD 1945, NKRI, dan Bhinneka Tunggal Ika dapat disebut atau dikategorikan menjadi Empat Pilar Kehidupan Berbangsa dan Bernegara atau Empat Pilar MPR RI. Namun, setelah putusan Mahkamah Konstitusi Nomor 100/PUU-XI/2013 yang menyatakan bahwa Empat Pilar Kehidupan Berbangsa dan Bernegara tidak dapat sahih sebagai tanda, maka sumber masalahnya terletak pada objeknya yaitu MPR RI. Sehingga, representamen dan intepretant menjadi tidak sinkron dan kacau yang sangat memungkinkan bahwa MPR RI sebagai konsepnya juga kacau.

Dalam konteks analisis teori kebenaran semantik, suatu pengetahuan dinyatakan benar jika diikuti oleh referensi yang benar pula (Aburaera, Muhadar, dan Maskun, 2013:251). Istilah Empat Pilar Kehidupan Berbangsa dan Bernegara yang terdiri atas Pancasila, 
UUD 1945, NKRI, dan Bhinneka Tunggal Ika tidak memiliki referensi yang jelas, sehingga secara semantik atau makna istilah Empat Pilar Kehidupan Berbangsa dan Bernegara adalah salah. Sebagaimana yang telah menjadi konsensus nasional dari berbagai referensi yang ada, menunjukkan bahwa Pancasila dan UUD 1945 merupakan sumber hukum nasional (Latif dan Ali, 2010:183), sehingga tidak dapat dikatakan sebagai Pilar Berbangsa dan Bernegara.

Merujuk pada teori makna atau arti yang dikembangkan oleh Alston, terdapat tiga pendekatan untuk memahami makna yaitu, 1). Pendekatan acuan (referential), 2). Pendekatan ideasional, dan 3). Pendekatan behavioral. Pendekatan acuan (referensial), menjelaskan bahwa suatu ungkapan atau kata harus mempunyai acuan agar ungkapan atau kata itu mengandung arti atau makna (Mustansyir, 1988:99-100). Pendekatan acuan dapat berasal dari benda, peristiwa, proses atau kenyataan. Pendekatan ideasional dapat diartikan sebagai suatu kalimat (bahasa) yang dihasilkan harus merujuk pada argumen atau reason (akal). Hal ini dikarenakan akal menentukan maksud dari bahasa itu sehingga bahasa yang diproduksi memiliki konvensi yang sama-sama dapat saling dimengerti. Pendekatan behavioral adalah makna suatu bahasa yang ditentukan oleh situasi dan kondisi lingkungan tertentu (Mustansyir, 2011:93).

Empat Pilar Kehidupan Berbangsa dan Bernegara yang terdiri dari Pancasila, UUD 1945, NKRI, dan Bhinneka Tunggal Ika menunjukkan bahwa: 1) Penggunaan istilah Empat Pilar Kehidupan Berbangsa dan Bernegara tidak dapat memiliki makna apapun karena sumber acuan atau rujukan dari istilah Empat Pilar tidak dapat dipertanggungjawabkan sumbernya. Berdasarkan teori acuan, Empat Pilar Berbangsa dan Bernegara nyatanya tidak memiliki dasar acuan yang jelas. Oleh karena itu, istilah tersebut tidak dapat memiliki makna sama sekali, 2) Pendekatan teori ideasional tidak dapat menunjukan bahwa Empat Pilar Kehidupan Berbangsa dan Bernegara memiliki dasar argumen yang cukup kuat untuk menjadi konsep yang dapat diterima secara nalar dan ilmiah. Selama ini, acuan ilmiah yang dimaksud oleh Empat Pilar hanya bertitik tolak pada sumber kamus bahasa Indonesia. Pengertian pilar dalam kamus bahasa Indonesia hanya merujuk 'pilar' yang berarti dasar. Sedangkan di dalam Empat Pilar Kehidupan Berbangsa dan Bernegara yang terdiri dari Pancasila, UUD 1945, NKRI, dan Bhinneka Tunggal Ika tidak semua dapat disebut dasar. Sehingga proses pemaknaan Empat Pilar menjadi kabur. 3). Pada pendekatan behavioral, makna Empat Pilar Kehidupan Berbangsa dan Bernegara dalam konteks situasi dan kondisi lingkungan di masyarakat tidak dapat diterima.

Pada lingkungan pendidikan dan akademik, berbagai kritik dan perbedaan pendapat muncul dalam pembahasan konsep Empat Pilar Kehidupan Berbangsa dan Bernegara. Sehingga, pada lingkungan masyarakat pendidik penggunaan istilah Empat Pilar tidak dapat diterima. Pada aspek situasi dan kondisi, terbentuknya Pancasila, UUD 1945, NKRI, dan Bhinneka Tunggal Ika memiliki peran dan fungsi yang berbeda. Makna atas Empat Pilar Kehidupan Berbangsa dan Bernegara dianggap absurd. 
Empat Pilar Berbangsa dan Bernegara yang digunakan oleh MPR RI dengan menyebutkan Pancasila, UUD 1945, NKRI, dan Bhinneka Tunggal Ika secara semiotik dalam teori Peirce menimbulkan persoalan. Dimensi semiotik yang muncul dalam representasi istilah Empat Pilar Berbangsa dan Bernegara secara qualisign tidak dapat mengindikasikan rujukan pada suatu pengertian yang sama atau satu kesatuan makna. Secara harfiah qualisign, istilah Empat Pilar Berbangsa dan Bernegara mengarahkan bahwa semua yang disebutkan di dalam kategori Empat Pilar ialah "pilar-pilar berbangsa dan bernegara". Namun, dalam konteks epistemologi bahasa, makna dan pengertian Pancasila, UUD 1945, NKRI, dan Bhinneka Tunggal Ika tidak dapat disamakan dengan pilar. Dengan demikian, Empat Pilar Berbangsa dan Bernegara tidak dapat menjadi ikon (kemiripan atau keserupaan) atas kehidupan berbangsa dan bernegara karena secara istilah tidak dapat merepresentasikan secara nasional sifat dan kemiripan dengan kehidupan berbangsa dan bernegara.

Istilah Empat Pilar Berbangsa dan Bernegara tidak dapat menunjukkan sinsign atau suatu peristiwa/fenomena masyarakat yang terjadi dan diterima sebagai kebenaran.Empat Pilar Berbangsa dan Bernegara tidak dapat menunjukkan suatu hubungan kausalitas dengan Pancasila, UUD 1945, NKRI, dan Bhinneka Tunggal Ika sebagai pembentuk negara dan bangsa Indonesia. Pada aspek dicent, menunjukkan bahwa Empat Pilar Berbangsa dan Bernegara merupakan bahasa politisi yang diproduksi untuk membangun dominasi dan hegemoni kekuasaan MPR RI. Secara simbolik, Empat Pilar Berbangsa dan Bernegara merupakan bentuk politik bahasa atas bahasa negara atau bahasa nasional yang telah ada digunakan, yang kemudian direproduksi oleh MPR $\mathrm{RI}$ dalam bentuk lain agar lebih populer menurut versi MPR RI.

Berdasarkan analisis semiotika di atas, dapat dinyatakan bahwa penggunaan istilah Empat Pilar telah mengubah cara pandang dan pemahaman kepada seseorang untuk memaknai dan memberikan pengertian ganda sehingga memunculkan persoalan sesat pikir karena tidak memiliki kerangka dasar acuan yang jelas yang dirujuk sebagai sumber makna semantis dari istilah Empat Pilar tersebut. Secara semiotik sintaktis, dinyatakan bahwa istilah Empat Pilar sebagai penanda salah satu bentuk bahasa komunikasi yang memiliki cara kerja dan fungsi yang sama. Sehingga secara kategori jenis dan struktur kata yang dimasukkan bertentangan antara satu dengan yang lainnya karena fungsi dan jenis kata tidak dapat disamakan. Secara semiotik semantik, dapat ditunjukkan bahwa istilah Empat Pilar sebagai penanda yang mengacu pada Pancasila, UUD 1945, NKRI, dan Bhinneka Tunggal Ika telah menimbulkan interpretasi yang beragam. Sehingga menyebabkan penggunaan istilah Empat Pilar tidak efektif dan menimbulkan pertentangan di masyarakat. Pancasila dalam teori semiotika Charles Sander Peirce adalah ikon (icon) dari bangsa Indonesia yaitu sebagai dasar negara dan tidak dapat digantikan menjadi istilah lain atau tidak mungkin diubah dengan istilah lain. Dalam konteks indeks, Pancasila berasal dari bangsa Indonesia, dan secara konkret nilai-nilai Pancasila telah ada 
dalam realitas kehidupan bangsa Indonesia. Dalam konteks hubungan simbol (symbol), Pancasila merupakan konsensus bersama (Kaelan, 2013:37). Melalui sidang PPKI, Pancasila ditetapkan sebagai dasar negara yang bersifat tetap dan tidak dapat diubah karena peristiwa sejarah bersifat sekali terjadi dan tidak dapat diulang (einmalig).

Secara semiotik pragmatik, penggunaan istilah Empat Pilar yang dituturkan oleh pemakai bahasa yaitu MPR RI dalam konteks komunikasi publik menimbulkan pertentangan dengan konteks pengertian istilah Pancasila, UUD 1945, NKRI, dan Bhinneka Tunggal Ika yang sebenarnya. Dasar pijakan yang tidak jelas dalam merumuskan istilah Empat Pilar telah menghasilkan ambiguitas terhadap proses pemaknaan istilah bahasa politik sebagai bentuk politisasi bahasa yang berdampak pada pengetahuan orang dalam memahami istilah Pancasila, UUD 1945, NKRI, dan Bhinneka Tunggal Ika. Penggunaan istilah tersebut secara jelas menimbulkan keraguan dalam memahami peran Pancasila, UUD 1945, NKRI, dan Bhinneka Tunggal Ika. Selain itu, menimbulkan inkonsistensi dalam penggunaan istilah yang selalu berubah-ubah.

\section{Politik Bahasa dalam Simbolisasi Em- pat Pilar}

Politik simbolik dalam bentuk bahasa yang telah digunakan oleh MPR RI melalui penggunaan istilah Empat Pilar Berbangsa dan Bernegara telah menciptakan pergeseran dan hegemoni simbolik atas bahasa. Seperti dalam kontruksi semiotika Peirce, terdapat objek, interpretan, dan simbol yang telah membawa proses pemaknaan di dalam benak seseorang dalam melihat istilah
Empat Pilar Berbangsa dan Bernegara menjadi bermakna ganda.

Legitimasi bahasa yang dibangun dengan penciptaan simbolik bahasa dari Empat Pilar Berbangsa dan Bernegara telah merekonstruksi pemikiran serta pemahaman masyarakat tentang keberadaan Pancasila, UUD 1945, NKRI, dan Bhinneka Tunggal Ika. Perekonstrusian tersebut dapat melalui berbagai media yang dibuat oleh MPR RI seperti talkshow, lomba, seminar, pelatihan, dan sosialisasi. Bahkan ada pula yang melalui majalah, tas, dan buku sebagai medianya. Politik bahasa yang dibentuk oleh MPR RI telah membawa implikasi pada pemahaman dan tafsir atas Pancasila, UUD 1945, NKRI, dan Bhinneka Tunggal Ika menjadi tidak pasti.

Hutton (2009), dalam tulisannya yang berjudul Language, Meaning, and the Law mengungkapkan bahwa bahasa sebagai medium hukum dapat dilihat dan memiliki sumber potensi ketidakkonsistenan dan ketidakpastian (Hutton, 2009:23). Hutton menekankan bahwa dalam pemikiran kefilsafatan dan politik terkait bahasa menunjukkan adanya suatu kekhawatiran bahwa bahasa dapat mengalami kegagalan sebagai media bertukar informasi. Kegagalan dalam penyampaian pesan oleh narasumber juga dapat menjadi sebab perpecahan sosial, manipulasi, dan kebingungan (Hutton, 2009:48).

Penggunaan istilah Empat Pilar Kehidupan Berbangsa dan Bernegara telah menimbulkan kerancuan. Kerancuan tersebut terjadi pada sistem ontologis, epistemologis, dan aksiologis dalam kerangka filsafat bahasa khususnya logika bahasa, semiotika bahasa, kedudukan dan fungsi, serta 
tata hubungannya. Sebagaimana diuraikan pada aspek ideologis Pancasila saat pasca reformasi dipahami sebagai bagian dari warisan rezim Orde Baru. Saat dimana berbagai ide dan konsep Pancasila yang baik cenderung dijauhkan dari masyarakat dan diskursus akademik mengarahkan Pancasila sebagai produk rezim Orde Baru pada awal gerakan reformasi muncul.

Pandangan umum tersebut membawa persepsi dan makna terhadap hakikat Pancasila yang berbeda dengan fakta sejarah yang ada di Indonesia. Kaelan menjelaskan saat era reformasi sejak tumbangnya kekuasaan Orde Baru muncul berbagai argumen politis terkait dengan pemahaman Pancasila sebagai suatu sistem pengetahuan. Dalam perkembangannya, berbagai argumen atau ungkapan tersebut menunjukkan adanya kekacauan epistemologis akan pemahaman Pancasila dan kekredilan pemikiran anak bangsa tentang filosofi dan kepribadian bangsanya. Pertama, penyamaan nilai, norma, dan praksis (fakta) dalam memahami Pancasila. Kedua, pada konteks politik, adanya penyamaan nilai-nilai Pancasila dengan suatu kekuasaan, rezim atau orde, sehingga berbicara Pancasila seakan-akan sebagai label Orde Baru dan identik dengan kekuasaan Soeharto. Ketiga, yang merupakan kekacauan yang sangat fatal adalah memahami dan meletakkan Pancasila sebagai suatu varian yang setingkat dengan agama (Kaelan, 2013:192).

Empat Pilar Kehidupan Berbangsa dan Bernegara dalam kedudukannya sebagai realitas yang ada masih perlu dikaji ulang. Empat Pilar tersebut belum memiliki dasar struktur logika bahasa yang benar. Logika bahasa yang digunakan dalam berbagai argumen yang ditawarkan oleh MPR RI, sebagaimana yang telah diuraikan, hanya menunjukkan logika bahasa yang dipakai sebatas menggunakan sumber dari Kamus Besar Bahasa Indonesia. Sehingga penggunaan istilah tersebut telah menimbulkan pertentangan dan perdebata dalam konteks logika bahasa dan ketentuan hukum yang berlaku. Hal ini disebabkan karena penggunaan istilah yang dicantumkan dalam peraturan perundang-undangan akan menimbulkan akibat hukum tertentu.

Penelitian ini menunjukkan bahwa; pertama, Empat Pilar Kehidupan Berbangsa dan Bernegara sebagai realitas yang ada, mengalami tiga bentuk kesalahan yaitu kesalahan semantik, kesalahan formal, dan kesalahan empiris (Basman, 2009:26). Kesalahan semantik disebabkan karena pemakaian katakata yang tidak teliti dan tidak tepat. Kesalahan formal diartikan bahwa ketika MPR RI mengambil keputusan dan kesimpulan ialah salah karena tidak sesuai dengan dasar pemikiran yang benar. Misalnya, MPR RI membuat kesimpulan tentang Empat Pilar Kehidupan Berbangsa dan Bernegara terdiri dari Pancasila, UUD 1945, NKRI, dan Bhinneka Tunggal Ika yang tidak sesuai dengan dasar pemikiran ilmiah dan secara formal bertentangan dengan dasar-dasar penjelasan ilmiah yang ada. Dalam konteks teori legitimasi pembenaran, Empat Pilar tidak memiliki dasar pembenar yang dapat dipertanggungjawabkan apabila dilihat dari legitimasi pembenaran, baik dari aspek legitimasi teleologis, sosiologis, yuridis, dan filosofis-etis. Legitimasi filosofis-etis lebih menekankan dan mempersoalkan keabsahan wewenang 
kekuasaan politik dari segi norma-norma moral (Nurtjahjo, 2005:20-21).

Sedangkan kesalahan empirik artinya adalah ketika MPR RI terlalu cepat melakukan generalisasi yang tergesa-gesa terhadap penggunaan istilah Empat Pilar Kehidupan Berbangsa dan Bernegara. Misalnya, MPR RI mengatakan bahwa "pilar" adalah dasar berdasarkan kamus Bahasa Indonesia tetapi istilah pilar dipakai untuk menggeneralisasikan Empat Pilar Kehidupan Berbangsa dan Bernegara yang terdiri Pancasila, UUD 1945, Bhinneka Tunggal Ika, dan NKRI. Sehingga istilah tersebut tidak dapat diuji secara empirik kebenarannya. Pancasila sebagai dasar negara, UUD 1945 sebagai konstitusi negara, NKRI sebagai 'bangunan negara'(Kaelan, 2012:20), dan Bhinneka Tunggal Ika sebagai semboyan negara Indonesia sudah sejak lama. Dasar-dasar itu sudah terdapat dalam alam kesadaran masyarakat Indonesia yang terbentuk dan terkonstruksikan melalui proses interpretasi. Proses interprestasi ini menyebabkan istilah tersebut berubah atau bergeser menjadi Empat Pilar Kehidupan Berbangsa dan Bernegara atau saat ini disebut sebagai Empat Pilar MPR RI yang telah mengacaukan pengetahuan masyarakat Indonesia tentang bangsa dan negara.

Kedua, sumber pengetahuan yang membentuk unsur Empat Pilar tersebut masih bertitik tolak pada otoritas kekuasaan. Empat Pilar Kehidupan Berbangsa dan Bernegara sebagai pengetahuan yang disusun dan dikembangkan oleh MPR RI terbentuk karena otoritas dan legitimasi politik penguasa yang mendasari adanya Pancasila, UUD 1945, NKRI, dan Bhinneka Tunggal Ika sebagai wujud Empat Pilar Berbangsa dan Bernegara. Hal ini dapat diartikan bahwa Empat Pilar tidak memiliki dasar kondisi kebenaran (truth condition) yang nyata.

Kondisi kebenaran (truth condition) ialah suatu objek yang pernyataan dapat menunjukkan secara faktual memiliki kebenaran yang objektif. Misalnya salju berwarna putih menunjukkan bahwa salju secara faktual berwarna putih, rumput berwarna hijau menunjukkan bahwa rumput secara faktual warnanya hijau itulah yang disebut sebagai truth condition (Baldwin, 2006:63). Empat Pilar Kehidupan Berbangsa dan Bernegara terjadi karena rekayasa bahasa dalam konteks istilah yang dilakukan oleh MPR RI sebagai pemilik otoritas negara. Otoritas dalam hal ini dimaknai sebagai hubungan antara seseorang/ institusi dengan orang lain sebagai subyek otoritas, dimana hubungan tersebut memberikan dasar alasan bagi subyek otoritas untuk bertindak atau melakukan sesuatu (Christman, 2002:25).

Secara sosiolinguistik, dapat ditunjukkan bahwa Empat Pilar Kehidupan Berbangsa dan Bernegara merupakan konsepsi politis, bukan sebagai pengetahuan yang lahir di masyarakat tentang nilai-nilai berbangsa dan bernegara. Pada ranah nalar publik, diketahui bahwa Empat Pilar Kehidupan Berbangsa dan Bernegara merupakan konsep yang tumpang tindih dan tidak dapat diterima oleh nalar publik karena tidak dapat direalisasikan oleh warga negara dan justru ditentang karena membingungkan. Sedangkan para politisi menggunakan nalar politisi yaitu nalar yang menggunakan aturan-aturan pragmatis dalam persaingan (Tjahjoko, 2016:xxxvii). Secara logika bahasa, ditemukan tidak 
ada titik temu antara logika bahasa publik dan logika bahasa politisi.

\section{SIMPULAN}

Berdasarkan hasil penelitian ini, disimpulkan bahwa penggunaan istilah Empat Pilar Berbangsa dan Bernegara yang dirumuskan oleh MPR RI secara garis besar telah menimbulkan tiga kerancuan mendasar yaitu 1).kerancuan semantik atas pemaknaan Pancasila, UUD 1945, NKRI, dan Bhinneka Tunggal Ika. 2). Kerancuan formal, mengubah makna formal baik dari aspek tanda tentang Pancasila, UUD 1945, NKRI, dan Bhinneka Tunggal Ika dan tidak sesuai dengan peraturan perundang-undangan.3). kerancuan empiris dalam aspek pragmatik yaitu makna empat pilar yang digunakan oleh MPR RI tidak sesuai dengan konteks yang makna yang digunakan di masyarakat dan sejarah.

Istilah Empat Pilar Berbangsa dan Bernegara yang digunakan oleh MPR RI merupakan salah satu bentuk lingual dalam proses penciptaan kebahasaan Empat Pilar Berbangsa dan Bernegara yang menimbulkan ketidakberaturan pemaknaan dan ketidakpastian makna atas kategori yang memasukkan Pancasila, UUD 1945, NKRI, dan Bhinneka Tunggal Ika menjadi satu varian sama.

Berdasarkan dari uraian analisis dan pembahasan kerangka semiotik Pierce dalam teori trikotomi bahwa: 1). Pada aspek representamen menunjukkan istilah Empat Pilar Kehidupan Berbangsa dan Bernegara yang terdiri atas Pancasila, UUD 1945, NKRI, dan Bhinneka Tunggal Ika tidak dapat merepresentasikan satu varian kategori yang sama yaitu sebagai pilar. 2). Pada aspek objek, Istilah Empat Pilar direpresentasikan sebagai program dari lembaga yang disebut MPR RI. 3). Pada aspek interpretant, menunjukkan bahwa makna Empat Pilar dipahami dengan berbagai macam tafsir, sehingga membingungkan masyarakat.

Istilah "Empat Pilar Berbangsa dan Bernegara" merupakan frasa yang tidak lazim dalam konteks sosiolinguistik masyarakat Indonesia. Istilah Empat Pilar Berbangsa dan Bernegara yang mengkategorikan Pancasila, UUD 1945, NKRI, dan Bhinneka Tunggal Ika merupakan bentuk kesalahan semantik dan pragmatik. Secara aturan penulisan simbol dan tanda, istilah tersebut bertentangan dengan hakikat kedudukan dan fungsi dari Pancasila, UUD 1945, NKRI, dan Bhinneka Tunggal Ika karena dijadikan sebagai satu varian yang sama, yaitu pilar; dalam semiotik Peirce, penggunaan istilah Empat Pilar Berbangsa dan Bernegara telah mengacaukan sistem tanda dan simbol, terutama pada makna semiotis Pancasila, UUD 1945, NKRI, dan Bhinneka Tunggal Ika. Sehingga antara representamen dan interpretant menjadi tidak sinkron dan kacau.

\section{UCAPAN TERIMA KASIH}

Naskah penelitian ini merupakan bagian dari penelitian Disertasi yang berjudul "Empat Pilar Kehidupan Berbangsa dan Bernegara Ditinjau dari Filsafat Bahasa dan Implikasi Teoritis terhadap Pemahaman Pancasila" pada program Pascasarjana Fakultas Filsafat, Universitas Gadjah Mada. Ucapan terima kasih saya sampaikan kepada Prof. Dr. Armaidy Armawi, selaku 
Promotor dan Prof. Dr. Kaelan, MS., selaku Ko-Promotor atas segala bimbingan, perhatian, dan kesabaran dalam membimbing peneliti menyelesaikan penulisan dan penelitian disertasi saya ucapkan terimakasih. Penulis juga mengucapkan terima kasih kepada Jurnal Litera yang telah menerbitkan naskah tulisan ini.

\section{DAFTAR PUSTAKA}

Aburaera, S., Muhadar, dan Maskun. 2013. Filsafat Hukum Teori dan Praktek, Jakarta: Kencan.

Baldwin, T. 2006. Philosophy of Language in the Twentieth Century in the Oxford Handbook of Philosophy of Language edited Ernets Lepore and Barry C. Smith, Oxford: Clarendon press.hal. 60-99.

Basman. 2009 . Filsafat Ilmu sebuah Pengantar, Yogyakarta: Gusepa.

Black, M. 1962. Dewey's Philosophy of Language, Source: The Journal of Philosophy, Vol. 59, No. 19 (Sep. 13, 1962), pp. 505-523. Published by: Journal of Philosophy, Inc.. Stable URL: http://www.jstor. org/stable/2023359. Accessed: 2910-2015 10:40.

Budi HH, S. 2000. Teknik-Teknik Analisa Media. Yogyakarta:Universitas Atmajaya.

Christman, J. 2002. Social and Political Philosophy a Contemporary Introduction, London: Routledge.

Detiknews. 2013. Taufiq Kiemas dan Sejarah Gagasan Empat Pilar. Diakses 21 Juni 2018 16:48, dari https:// news.detik.com/berita/2268539/ taufiq-kiemas-dan-sejarah-gagasanempat-pilar-.

Eco, U. 1979. A Theory of Semiotics, USA: Indiana University Press.
Hadiatie, D.A. 2014. 4 Pilar Kebangsaan dalam Bingkai Kritik. Diakses 21 Juni 2018, 15:43, dari https://www. kompasiana.com/dwiearoem/4pilar-kebangsaan-dalam-bingkaikritik_552aa14df17e618529d623b0.

Hutton, C. 2009. Language, Meaning, and The Law. England: Edinburgh University Press.

Kaelan. 2012. Problem Epistemologis Empat Pilar Berbangsa dan Bernegara, Yogyakarta: Paradigma.

Kaelan. 2013. Negara Kebangsaan Pancasila, Kultural, Historis, Filosofis, Yuridis, dan Aktualisasnya, Yogyakarta: Paradigma.

Keraf, G. 1984. Tata Bahasa Indonesia Sekolah Menengah Tingkat Atas, cetakan X, Flores: Nusa Indah.

Latif, A. dan Ali Hasbi. 2010. Politik Hukum, Jakarta: Sinar Grafika.

Lestaria, E. 2014. Implikasi Yuridis Putusan Mahkamah Konstitusi Nomor 34/PUU-XI/2013 terhadap Pemenuhan Asas Kepastian Hukum dan Keadilan. Tesis. Yogyakarta: Fakultas Hukum UGM.

Mauws, M. K., dan Phillips. Nelson. 1995. Understanding Language Games. Source: Organization Science, Vol. 6, No. 3 (May - Jun., 1995), pp. 322-334. Published by: INFORMS. Stable URL: http://www.jstor. org/stable/2635254. Accessed: 2910-2015 10:52.

Mustansyir, R. 1988. Filsafat Bahasa Aneka Masalah Arti dan Upaya Pemecahannya, Jakarta: Prima Karya.

Mustansyir, R. 2011. Filsafat Tanda Charles Sanders Peirce dalam Perspektif Filsafat Analitis dan Relevansinya bagi Budaya Kontemporer di Indonesia. Disertasi. Yogyakarta: Fakultas Filsafat. 
Nurtjahjo, H. 2005. Ilmu Negara Pengembangan Teori Bernegara dan Suplemen, Jakarta: Rajawali Press.

News.okezone.com. 2013. Pancasila Tak Pantas dijadikan 4 Pilar Kebangsaan. Diakses 21 Juni 2018, 18:16, darihttps://news.okezone.com/ $\mathrm{read} / 2013 / 09 / 30 / 339 / 874389 /$ pancasila-tak-pantas-dijadikan-4pilar-kebangsaan.

Pimpinan MPR RI dan Tim kerja Sosialisasi MPR RI periode 20092014.(2012). Empat Pilar Kehidupan Berbangsa dan Bernegara, Jakarta: MPR RI.

Prasad, K.S. Ed. 2002. The Philosophy of Language in Classical Indian Tradition. New Delhi: Decent Books.

Putusan Mahkamah Konstitusi Nomor 100/PUU-XI/2013.

Sobur, A. 2009. Semiotika Komunikasi (cetakan Keempat). Bandung: PT Remaja Rosdakarya.

Suantoko. 2017. Makna Simbol Sastra Lisan Tanduk Masyarakat Adat Genaharjo Kabupaten Tuban. Jurnal Dialektika, Volume 2, Juni 2017, hlm.41-70.

Supardiyono. 2013. Kritik Terhadap Diskursus 4 Pilar Kebangsaan. Diakses 21 Juni 2018 16:25, dari https://www. kompasiana.com/sapardiyono/ kritik-terhadap-diskursus-4-pilar-ke bangsaan_552b98e26ea834302b8b 458a.
Tjahjoko, G. T. 2016. Politik Ambivalensi, Nalar Elite di Balik Pemenangan Pilkada, Yogyakarta: Polgov UGM.

Undang-Undang Dasar Republik Indonesia 1945.

Undang-Undang Nomor 2 tahun 2011 tentang Perubahan Atas UndangUndang Nomor 2 tahun 2008 tentang partai politik.

Ugm.ac.id. 2013. PSP UGM Koreksi 4 Pilar Kebangsaan. Diakses 20 Juni 2018 18:31, dari https://ugm. ac.id/id/berita/8195-psp.ugm. koreksi.4.pilar.kebangsaan.

Wildan, M. 2013. Kritik 4 Pilar. Diakses 21 Juni 2018 15:56, dari https:// www.kompasiana.com/willdhanne/kritik-4 pilar.

van Zoest, Aart. 1992. Interpretasi dan Semiotika dalam Serba-Serbi Semiotika (Penyunting Panuti Sudjiman dan van Zoest), Jakarta: Gramedia Pustaka. Hal. 1-25.

\section{Majalah}

Majalah Majelis, edisi No.12/TH.X/ Desember 2016.

Majalah Majelis, edisi No.01/TH.XI/ Januari 2017. 